Author Accepted Manuscript Published by Slavic Review

The manuscript has been published and appears in a revised form subject to input from the Journal's editor.

$\underline{\text { Slavic Review, }}$ Volume 80, Issue 2, Summer 2021 , pp. 224 - 233

DOI: https://doi.org/10.1017/slr.2021.77

Marina Yusupova

\title{
The Invisibility of Race in Sociological Research on Contemporary Russia: A Decolonial Intervention
}

\begin{abstract}
This essay provides a critical decolonial intervention into the prevalent state of racial exceptionalism in mainstream sociological research on contemporary Russia. Following critical race theory's understanding of race as relationally constituted and rooted in discourses of Europeanness, modernity, and civilization, the essay shows that race is highly prevalent but unacknowledged in sociological studies of Russia. It is argued that dismissing race as analytically irrelevant in Russia seriously limits the sociological ability to explain social inequalities, engage with current global challenges and inadvertently gives racism new legitimacy. Drawing on postcolonial and decolonial critiques of sociology as a form of knowledge production, the essay points towards some ways of decolonizing sociological research concerning the inequalities associated with race and ethnicity in Russia and overcoming racial exceptionalism.
\end{abstract}

There has long been a general conviction among both scholars and the Russian population that race has nothing to do with Russia. People historically residing in the territory of contemporary Russia had different ethnicities (narodnost'), nationalities (natsional'nost'), religious affiliations, cultural backgrounds, but not 
race. The general view was that race and racism were phenomena driving West European colonial projects, but not Russian imperial expansion or Soviet policies. For a long time, historians of Russia, including those in the west, subscribed to the same view, which is still widely present in the scholarship. ${ }^{1}$ It is only recently that scholars have begun to pay attention to the role of race in the post-Soviet region and refuted claims that race was irrelevant for understanding Russian/Soviet politics and society. ${ }^{2}$ These insights, however, are rarely used in the mainstream social science research on contemporary Russia. Sociological accounts continue to interpret prejudice towards and discrimination against people of 'non-Slavic appearance' (the expression widely used by the media and politicians) and migrants from ex-Soviet regions of Caucasus and Central Asia through the notions of xenophobia, migrantophobia, and ethnic conflict.

\section{Silence about Race}

Refusal to see race in sociological scholarship takes not one but many forms, though all contain an unspoken but powerful attachment to and/or identification of Russia and Russianness with what critical race theory calls 'whiteness.' ${ }^{3}$ Some forms of racial exceptionalism include direct statements of non-applicability of race to the Russian context. Reporting the results of their research on inter-ethnic relations in higher education, Tatyana Bulatova and Andrey Glukhov explain:

\footnotetext{
${ }^{1}$ For example, Nathaniel Knight, "Vocabularies of Difference: Ethnicity and Race in Late Imperial and Early Soviet Russia," Kritika: Explorations in Russian and Eurasian History 13, no 3 (2012): 667-683.

${ }^{2}$ For example, see, among others, Nikolay Zakharov, Race and Racism in Russia (Basingstoke, 2015); Jennifer Suchland, "The LGBT Specter in Russia: Refusing Queerness, Claiming 'Whiteness," Gender, Place and Culture: A Journal of Feminist Geography 25, no 7 (2018): 1073-1088; David Rainbow, ed., Ideologies of Race: Imperial Russia and the Soviet Union in Global Context (Montreal, 2019); Vera Tolz, "Discourses on Race in Imperial Russia (18301914)," in The Invention of Race: Scientific and Popular Representations, eds. Nicolas Bancel, Thomas David, and Dominic Thomas, (London, 2014), 130-144; Marina Mogilner, Homo Imperii: A History of Physical Anthropology in Russia (Lincoln, 2013); Eric D. Weitz, "Racial Politics without the Concept of Race: Reevaluating Soviet Ethnic and National Purges," Slavic Review 61, no 1 (2002): 1-29; and Daria Krivonos, "Migration On the Edge of Whiteness: Young Russian-speaking Migrants in Helsinki, Finland" (PhD Diss., University of Helsinki, 2019), at https://helda.helsinki.fi/handle/10138/304004 (accessed April 30, 2021).

${ }^{3}$ See, for example, Catherine Baker, Race and the Yugoslav Region: Postsocialist, Post-Conflict, Postcolonial? (Manchester, 2018); Charles Mills, The Racial Contract (New York, 1997); Michelle Christian, "A Global Critical Race and Racism Framework: Racial Entanglements and Deep and Malleable Whiteness," Sociology of Race and Ethnicity 5, no 2 (2019):169-185.
} 
In Western studies, hierarchical differences between immigrants and the receiving society have been interpreted primarily in racial terms. The history of Russia has not been burdened by racial confrontation and discrimination; therefore, the Russian mass consciousness is not burdened by racial prejudices that can affect the attitude towards migrants. ${ }^{4}$

While rarely articulated in such direct form, the mainstream sociological research on Russia implicitly accepts the outlined position as an unquestionable historical fact. Other common forms of exceptionalism include discussing racism and racialization in Russia without any connection to race; studying racism as a form of enthicized xenophobia; using theories of race and racial inequalities coined in the Western contexts to address 'ethnic inequalities' in Russia; and approaching race as just another category of diversity parallel to gender or age. As is the case in other world contexts characterized by racial exceptionalism, race in sociological research on Russia is replaced with other signifiers such as 'culture', 'ethnicity' or 'background. ${ }^{5}$

It is not always the concept of race itself that is omitted. Some recent sociological studies link racism in Russia to the history of Russian imperialism and build their analysis on postcolonial approaches to race as 'a political project rooted in colonialism and imperialism' or 'a trait belonging to the host society' rather than an individual characteristic of a migrant experiencing racism and racialization. ${ }^{6}$ It is the absence of consideration of how the boundedness of race, modernity and Europeanness are reflected in Russianness.

\footnotetext{
4 Tatyana Bulatova and Andrey Glukhov, "Sostoianie mezhetnicheskikh otnoshenii v Tomske v otsenke obrazovatel'nykh migrantov," Tomsk State University Journal of Philosophy, Sociology and Political Science 43 (2018): 118 [my translation from Russian].

${ }^{5}$ Alana Lentin, "Europe and the Silence about Race," European Journal of Social Theory 11, no 4 (2008): 496; Catherine Baker, "Postcoloniality Without Race? Racial Exceptionalism and Southeast European Cultural Studies," Interventions 20, no 6 (2018): 759-784.

${ }^{6}$ First quote: Irina Kuznetsova and John Round, "Postcolonial migrations in Russia: the racism, informality and discrimination nexus," International Journal of Sociology and Social Policy 39, no 1/2 (2018): 55 with reference to Kibria et al. (2013, p. 5); second quote: Victor Agadjanian, Cecilia Menjívar and Natalya Zotova, "Legality, Racialization, and Immigrants' Experience of Ethnoracial Harassment in Russia," Social Problems 64, no 4 (2017): 559.
} 
Race in Russia continues to be solely and exclusively about the Other - 'migrants', 'blacks', 'Asians', 'Muslims', never about Russians. ${ }^{7}$

Critical race theorists have long argued that race, both an ally and a product of European colonial expansion since the early sixteenth century, attains its meaning through 'the interaction of the oppositional, yet mutually dependent, relationship between Europeanness and non-Europeanness', between the notions of modernity and primitiveness. ${ }^{8}$ According to Barnor Hesse, the modern conceptual history of race shows that race can mean many things and be assigned to corporeal, geographical, cultural, religious, historical [insert a never-ending list of] differences in modernity's construction of hierarchy between 'Europeanness' and 'non-Europeanness', which is invariably based on the notions of supremacy of 'white'/'European' people over those marked as 'non-white/non-European.' ${ }^{9}$ In other words, it is suggested that we should understand race relationally, rather than proprietarily (as property of individuals).

In a search to understand how racial differences are produced and gain symbolic and material power in the world, 'it is whiteness that is more important than blackness,' because 'what constitutes the other as black (or as corporeally oppositional) is the European Enlightenment obsession with the aesthetics of its own whiteness. ${ }^{10}$ Now how is 'whiteness as a conjunction of Europeanness and modernity' relevant to Russia (commonly positioned as a non-Western, (post-)imperial power in an ambiguous, contradictory relationship with Europe and European modernity), which had not historically used the concept of race in managing and understanding its human diversity? ${ }^{11}$ Is whiteness, as critical race theory understands it, even relevant to Russia?

Some recent studies of post-Soviet Russian-speaking migrants in Finland, Italy and the US show that, while these migrants may be racialized as not-quite-white in the western contexts, they simultaneously

\footnotetext{
${ }^{7}$ Lentin, "Europe and the Silence about Race," 493.

${ }^{8}$ Lentin, "Europe and the Silence about Race," 493.

${ }^{9}$ Barnor Hesse, "Racialized modernity: An analytics of white mythologies," Ethnic and Racial Studies 30, no 4 (2007): 653-655.

${ }^{10}$ Hesse, "Racialized Modernity," cited in Lentin, "Europe and the Silence about Race," 494.

${ }^{11}$ Baker, "Postcoloniality without Race?," 778.
} 
firmly insist on their own whiteness. ${ }^{12}$ It nevertheless remains almost entirely unexamined how Russian whiteness operates at home. ${ }^{13}$ If, as documented by numerous research and public opinion polls, some 'nonethnically Russian/Slavic' people in Russia are racialized as 'black', then who is white? If Russians express superiority towards peoples and world regions racialized as non-European and non-white, does it mean that they see themselves as white? How did Russians become white? What about so-called Slavic people? Why are Ukrainians and Belarusians generally accepted into whiteness, but Tatars and Georgians are not? ${ }^{14}$ Until these questions are explored; until whiteness stays silently embedded in Russianness, race will remain invisible.

\section{Silence or Silent Screaming?}

Why do we even need race to research diversity and inequalities in contemporary Russia? According to the 'proud' history of internationalism and anti-racism in the Soviet Union, race is an embarrassment, it is immoral, something that humanity has to leave behind once and for all. We need race because, in the words of David Goldberg, race, as 'ways of being, living, thinking, [and] emoting' 'refuses to stay silent.'15 Despite the prevalent state of racial exceptionalism in sociological scholarship on the Russian context, this scholarship screams of race.

For instance, we can observe that existing 'ethnic hierarchies' social scientists refer to in the Russian context are based on conceptions of Europeanness and non-Europeanness. Alexey Bessudnov and Andrey Shcherbak found that employers in Moscow and St Petersburg discriminate against visible ethnic

\footnotetext{
12 Daria Krivonos, "Claims to whiteness: Young unemployed Russian-speakers' declassificatory struggles in Finland," The Sociological Review 66, no 6 (2018): 1145-1160; Martina Cvajner, Soviet Signoras: Personal and Collective Transformations in Eastern European Migration (Chicago, 2019); Claudia Sadowski-Smith, The New Immigrant Whiteness: Race, Neoliberalism, and Post-Soviet Migration to the United States (New York, 2018).

${ }_{13}$ Verdana Veličković makes a similar point in relation to East Europeans. See Vedrana Veličković, "Belated Alliances? Tracing the Intersections between Postcolonialism and Postcommunism," Journal of Postcolonial Writing 48, no 2 (2012): 171.

${ }^{14}$ Catherine Baker asks similar questions in relation to the Balkans in her "Postcoloniality without Race?," 767.

${ }^{15}$ David Goldberg, "Racial Europeanization," Ethnic and Racial Studies 29, no 2 (2006): 337 cited in Lentin, "Europe and the Silence about Race," 491.
} 
minorities of 'non-European origin', but not against groups of 'European origin. ${ }^{16}$ In their field experiment of ethnic discrimination in Russia, researchers combined 'all ethnic groups into two categories: of European origin (Germans, Jews, Latvians and Lithuanians, ethnic Russians, and Ukrainians) and of non-European origin (Armenians, Azerbaijanis and Chechens, Georgians, Tajiks and Uzbeks, and Tatars). ${ }^{, 17}$ Furthermore, reading sociological scholarship on migration, one discovers that much of this scholarship approaches human diversity in Russia in the binary terms of 'ethnic Russians' and 'ethnic non-Russians' (often just 'non-Russians'), where the latter category includes over a hundred ethnicities living on the territory of the Russian Federation. ${ }^{18}$ This effectively means that the ontological status of millions of people is defined through 'not being' and points to Russianness as the most crucial but overlooked category of analysis. The amount of unaccounted racial slurs and racially charged language deriving from empirical datasets and directed at 'ethnically non-Russian' people is equally striking. Much of this language directly relates to bodies, development and civilization - the main markers of race. For example, Svetlana Bodrunova et al.'s research reports that North Caucasians are described as 'inferior,' 'barbarians,' 'uncultivated' and 'enfants terribles of Mother Russia. ${ }^{19}$ Ekaterina Demintseva's and Félicie Kempf's studies of 'migrant schools' in Moscow ('schools that are attended by a large number of 'non-Russian' pupils') reveal that 'non-Russian' children are called 'black' and described as 'aggressive', 'unable to assimilate', and 'carrying and spreading diseases. $^{20}$

\footnotetext{
${ }^{16}$ Alexey Bessudnov and Andrey Shcherbak, "Ethnic Discrimination in Multi-ethnic Societies: Evidence from Russia," European Sociological Review 36, no 1 (2020), 104-120.

${ }^{17}$ Bessudnov and Shcherbak, "Ethnic Discrimination," 113.

${ }^{18}$ See, for example, Mikhail Alexseev, "Majority and Minority Xenophobia in Russia: The Importance of Being Titulars," Post-Soviet Affairs 26, no 2 (2010): 89-120; Zuzanna Brunarska, "Anti-immigrant Attitudes in Russia: The Group Position Model Reconsidered," Europe-Asia Studies 71, no 9 (2019): 1508-1531; Irina Britvina and Polina Shumilova, "Kul'turnaia identichnost' i problemy adaptatsii inoetnichnykh migrantov v Rossii," RUDN Journal of Sociology 17, no 3 (2017): 317-326.

${ }^{19}$ Svetlana Bodrunova, Olessia Koltsova, Sergey Koltcov, and Sergey Nikolenko, "Who's Bad? Attitudes Toward Resettlers From the Post-Soviet South Versus Other Nations in the Russian Blogosphere," International Journal of Communication 11(2017): 3242-3264.

${ }^{20}$ Ekaterina Demintseva, “'Migrant schools' and the 'children of migrants': constructing boundaries around and inside school space," Race Ethnicity and Education 23, no 4 (2020): 598-612; Félicie Kempf, "School Choice and the Children of Migrants: Unveiling Everyday Migrantophobia in Moscow," Laboratorium: Russian Review of Social Research 12, no 1 (2020): 127-151.
} 
Dismissing race, as something that does not originate from Russian history, culture or politics and therefore does not matter, is ubiquitous in the scholarship and limits our ability to see and analyze. As a result, such obviously global processes as the racialization of migration and discrimination against othered populations in Russia are interpreted in narrow nationalist terms (e.g. as a consequence of national identity crisis) or reduced to psychological traits. ${ }^{21}$ Overall these examples demonstrate that mainstream sociological research concerning the inequalities associated with race and ethnicity in Russia is unable to adequately explain these inequalities, 'to engage with current global challenges' and, at worst, contributes to the naturalization of social hierarchies, the proliferation of racial violence, and inhibiting development of public debates. ${ }^{22}$ Following Gurminder Bhambra, I do not view this as 'an error of individual scholarship... but something that is made possible by the very disciplinary structure of knowledge production $\left[\right.$ in] ... the modern sociology. ${ }^{23}$

\section{Decolonizing Sociology}

In the remaining part of this essay, I build on the postcolonial and decolonial critiques of sociology and its failure to address the inextricable connection that exists between the notions of race, the rhetoric of modernity, and the histories of European colonial violence against those marked as 'non-Europeans. ${ }^{\text {, }}$ The starting point for these critiques lies in approaching sociology as a form of knowledge that emerged in the nineteenth century 'as a debate among the intellectuals of the imperial centre about the world that global imperialist had encountered or created. ${ }^{, 25}$ Raewyn Connell writes that one of the key organizing concepts of Comtean sociology (ca. 1850-1920) was interpreting 'the difference between the metropole and the

\footnotetext{
${ }^{21}$ Anastasia Gorodzeisky and Anya Glikman, "Two Peoples - Two Stories: Anti-Immigrant Attitudes in Post-Socialist Russia," Social Problems 65 (2018): 543-563; Vladimir Mukomel', “Ksenofoby i ikh antipody: kto oni?," Mir Rossii 26, no 1 (2017): 32-57.

${ }^{22}$ Gurminder Bhambra, "Postcolonial Reflections on Sociology," Sociology 50, no 5 (2016): 961.

${ }^{23}$ Gurminder Bhambra, "The Possibilities of, and for, Global Sociology: A Postcolonial Perspective," in Postcolonial Sociology, ed. Julian Go (Bingley, 2013), 300.

${ }^{24}$ See Julian Go, "Postcolonial Possibilities for the Sociology of Race," Sociology of Race and Ethnicity 4, no 4 (2018): 439-451; Gurminder K. Bhambra, Connected Sociologies (London, 2014); Ali Meghji, Decolonizing Sociology: An Introduction (Cambridge, UK, 2021).

${ }^{25}$ Raewyn Connell, "The sociology of gender in Southern perspective," Current Sociology Monograph 62, no 4 (2014): 551.
} 
colony... as "progress." 26 Ali Meghji explains that from its inception, sociology "internalized the logic of a colonial episteme', that is, it accepted 'the dominant ways of thinking and knowing that produced and reproduced colonial difference: the idea that the colonized were inherently different from (and inferior to) the Western colonizers. ${ }^{27}$

As shown by historical research on intellectual currents in late imperial Russia, Russian social sciences including sociology 'were thoroughly integrated into the European and, later, transatlantic intellectual context'; their approaches to human diversity and discourses on racial and ethnic difference were in line with the dominant episteme of European modernity. ${ }^{28}$ Some scholars present Russian sociology as a long-lasting intellectual tradition reaching back to the nineteenth century and 'unified by a set of underlying common features. ${ }^{, 29}$ Others consider it as a new field of study which emerged in the post-Soviet period and was shaped by numerous (and mostly) western social theories. ${ }^{30}$ In either case, as demonstrated above, mainstream sociology concerning the inequalities associated with race and ethnicity in Russia shares disciplinary structure of knowledge production with European and American sociologies in that it fails to address the relationship between sociology and empire.

Bhambra suggests that sociology - a discipline approaching race and ethnicity as issues of stratification and identity - can be criticized on three grounds: substantive, conceptual/methodological, and epistemological. ${ }^{31}$ I follow the structure of her critique to explain what can be done to overcome racial exceptionalism in sociological research about Russia.

\section{Substantive Issues}

\footnotetext{
${ }^{26}$ Connell, "The sociology of gender," 551.

${ }^{27}$ Meghji, Decolonizing Sociology, 3.

${ }^{28}$ Alexander Semyonov, Marina Mogilner, and Ilya Gerasimov, "Russian Sociology in Imperial Context," in Sociology and Empire: The Imperial Entanglements of a Discipline, ed. George Steinmetz, (Durham, NC, 2013): 54; Tolz, "Discourses on Race in Imperial Russia."

${ }^{29}$ Pavel Sorokin, "The Russian Sociological Tradition from the XIXth Century until the Present: Key Features and Possible Value for Current Discussions," The American Sociologist 46 (2015): 342.

${ }^{30}$ Elena Zdravomyslova, “"Make Way for Professional Sociology!': Public Sociology in the Russian Context," Current Sociology 56, no 3 (2008): 405-414.

${ }^{31}$ Bhambra, "Postcolonial Reflections," 961.
} 
Postcolonial and decolonial theorists have argued that the way in which sociological research understands the past and how this understanding influences its conceptualization and analysis of the present is problematic. $^{32}$ In Bhambra's words 'the historical record... found within standard sociological understanding' lacks 'a systematic consideration of the world-historical processes of dispossession, appropriation, genocide, and enslavement as central to the emergence and development of modernity and its institutional forms. ${ }^{33}$ This critique is applicable to the sociology of race and ethnicity in Russia, since the historical account found in existing studies is generally based on an implicit acceptance of the official Soviet state narrative on the equality of all Soviet ethnicities/nationalities and/or privileging Eurocentric (or to be precise Russian-centric) account of the emergence of modernity in the region. Ignoring Russia's history as a country that over multiple stages of colonization slaughtered, displaced, and enslaved multiple peoples, hinders the sociological ability to explain the present-day inequalities. To understand why Russians today continue to draw their sense of civilizational superiority over Chechens, Armenians, Kazakhs, Buryats, Uzbeks and others, routinely called various racist terms, the histories of Russian and Soviet colonialism has to be taken into account.

Considering imperial Russia's, the Soviet Union's and the Russian Federation's positionality within global imperial formations is another crucial issue that can help make sociological research in and about Russia a more critical endeavor. It is commonly known that from the early eighteenth century onwards Russia engaged in selective borrowing of elements of western modernity. While the history of Russia's cultural and intellectual dependency on Europe has various, often contradicting, interpretations from stressing Russia's uniqueness to claims of mental colonization by western philosophy, knowledge and cultures - a lack of attention to the power of the western accounts of modernity/coloniality in Russia reinforces the legitimacies of these accounts. ${ }^{34}$

\footnotetext{
${ }^{32}$ Bhambra, "The Possibilities of, and for, Global Sociology," 309; Go, "Postcolonial Possibilities."

${ }^{33}$ Bhambra, "Postcolonial Reflections," 962.

${ }^{34}$ The former interpretation can be found in Kevork K. Oskanian, "A Very Ambiguous Empire: Russia's Hybrid Exceptionalism," Europe-Asia Studies 70, no 1 (2018): 26-52; the latter belongs to Madina Tlostanova, "The Janusfaced Empire Distorting Orientalist Discourses: Gender, Race and Religion in the Russian/(post)Soviet Constructions of the "Orient"," Worlds \& Knowledges Otherwise (Spring 2008): 1-11.
} 


\section{Conceptual/Methodological Issues}

As noted above, sociological research has been criticized for approaching ethnicity and race as primarily issues of stratification and/or identity. While focus on stratification and identity has a crucial importance for understanding human societies, it has a limited capacity to unveil 'the underlying processes by which race and ethnic differences are produced. ${ }^{35}$ This criticism is further exacerbated by a widespread lack of conceptual clarity in sociological research on Russia - the central concepts of 'race' and 'ethnicity', 'racism' and 'xenophobia' often remain undefined and/or conflated with each other. When defined, racism for the most part is seen as prejudice or discrimination against individuals with a different skin colour or phenotypical traits; infantilization of non-Slavic or non-European people on the basis of their perceived lack of 'civilization', 'progress' or 'culture' is rarely recognized as racism at all. ${ }^{36}$ Developing clear definitions for the central research terms and recognizing race and racism as world-systemic phenomena linking global geographies through connected notions of white supremacy, modernity and Europeanness might be a useful way forward. ${ }^{37}$

Recognizing connections between global geographies and politics of race is imperative for another important reason - overcoming methodological nationalism: the intellectual orientation to research and analyze exclusively within the framework of the nation-state. ${ }^{38}$ Racialized hierarchies and oppression cut across national boundaries, because an empire that invented such hierarchies and oppression was 'a transnational and global process. ${ }^{39}$ Correspondingly, in Ulrich Beck's terms some social processes 'are indifferent to national boundaries. ${ }^{40}$ This is not to say that there is a lack of cross-country comparisons between everyday racism and anti-immigration attitudes in Russia and elsewhere. Within sociological

\footnotetext{
${ }^{35}$ Bhambra, "Postcolonial Reflections," 961, emphasis is original.

${ }^{36}$ Goldberg, The Racial State (Malden, MA, 2002).

${ }^{37}$ Christian, "A Global Critical Race and Racism Framework."

${ }^{38}$ Andreas Wimmer and Nina Glick Glick, "Methodological nationalism and beyond: nation-state building, migration and the social sciences," Global Networks 2, no 4 (2002): 301- 334; Ulrich Beck, "The cosmopolitan perspective: Sociology of the second age of modernity," British Journal of Sociology 51, no 1 (2006): 79-105.

${ }^{39}$ Go, "Postcolonial Possibilities," 447.

${ }^{40}$ Beck, "The cosmopolitan perspective," 80.
} 
scholarship these comparisons and parallels are plentiful. As argued by Julian Go, what is often missing is the attention to transnational connections between technologies of power and domination generated by processes of colonialism and deployed against the racialized others at home and abroad. ${ }^{41}$ Investigating these connections will be instrumental in overcoming racial exceptionalism without diminishing the specificities of the Russian context.

\section{Epistemological Issues}

Postcolonial and decolonial critiques urge sociology of race and ethnicity to break away from the imperial episteme and decolonize the discipline. ${ }^{42}$ Decolonizing means 'making visible the invisible and... analysing the mechanisms that produce such invisibility. ${ }^{, 43}$ As many have argued, whiteness gains currency by being invisible, by being 'the absent centre against which others appear only as deviants, or points of deviation. ${ }^{, 4}$ To decolonize also means to recognize that racial exceptionalism in Russia, historically the third largest empire in the world, is an effect of global coloniality - the system of power relations and classificatory order privileging European/white people and the Eurocentric way of life, while marginalizing those marked as non-European/non-western/non-white peoples worldwide. ${ }^{45}$

Up to date mainstream sociological research concerning race and ethnicity in Russia has mainly focused either on the Russian 'majorities' attitudes towards 'ethnic minorities' or the experiences of oppression and exploitation among 'ethnic' labour migrants. These research orientations not only reinforce the perception that Russia is the country of ethnic Russians but also produce significant omissions in the knowledge production - namely, they obliterate the role of the margins in constituting the core. ${ }^{46}$ For instance, the racializing discourses that the Russian state has projected on migrants from ex-Soviet countries

\footnotetext{
${ }^{41}$ Go, "Postcolonial Possibilities," 447.

42 Bhambra, "Postcolonial Reflections"; Go, "Postcolonial Possibilities"; Meghji, Decolonizing Sociology.

${ }^{43}$ Nelson Maldonado-Torres, "On the coloniality of being: Contributions to the development of a concept," Cultural Studies 21 (2007): 262.

${ }^{44}$ Sara Ahmed, "A phenomenology of whiteness," Feminist Theory 8, no 2 (2007): 157.

45 Aníbal Quijano, "Coloniality of Power and Eurocentrism in Latin America," International Sociology 15 , no 2 (2000): 215-232.

${ }^{46}$ Edward Said, Orientalism (New York, 1979).
} 
have been discussed at length, but what does this projection do for the Russian state itself? Could it be the case that whiteness that ethnic Russians ascribes to themselves only exists in the presence of racialized migrants? A shift from approaching migrants and racialized populations as 'minorities' among Russian 'majority' to examination of the constitutive role they play in the formation of Russianness and the Russian state will help to decolonize Russian sociology. In contrast to seeing Russianness as an indigenous category, formed independently of the history of Russian/Soviet imperialism, and migrants from the ex-Soviet states to Russia as newcomers, these processes should be located 'within the broader systems of nation-state formation in the context of imperial states and colonial regimes and therefore to be understood as integral to such processes as opposed to being regarded as subsequent additions to them. ${ }^{47}$

\section{Conclusion}

The decolonial project has shown that analytical categories of social sciences are not neutral, may contribute to sustaining the hegemonic structures of power and reinforce social inequalities. From the viewpoint of this essay, mainstream sociological research concerning race and ethnicity in the Russian context not only fails to recognize the link between existing inequalities and modernity/coloniality but also lacks the analytical tools to think critically about these inequalities. The scope of this essay does not allow for a detailed overview of the sociological approaches to race and ethnicity that successfully engage with postcolonial and decolonial tools of critique. ${ }^{48}$ Following critical race theory's understanding of race as relationally constituted and adopting the structure of Bhambra's critique, this essay elaborates on a number of substantive, conceptual/methodological and epistemological issues that sociologists of Russia may find useful to consider while devising their research projects.

Last but not least, decolonizing Russian sociology of race and ethnicity presents a valuable opportunity to further develop the theorization of continuities and discontinuities of inequalities first forged by colonialism into the present. As argued by Sergey Abashin, the Russian case pointedly demonstrates

\footnotetext{
${ }^{47}$ Bhambra, "The Possibilities of, and for, Global Sociology," 311.

${ }^{48}$ Such an overview can be found in Go, "Postcolonial Possibilities."
} 
that postcolonialism can emerge from 'a combination of contemporary conditions, and not necessarily stems exclusively and directly from the... past. ${ }^{49}$ On the one hand, as discussed above, modern-day inequalities in Russia reflect those first produced by Russian and Soviet colonial expansion. On the other hand, it has been argued that the dramatic and sudden fall of the Russian empire and the Soviet Union disrupted and/or put an end to multiple colonial processes that took place within these imperial formations. ${ }^{50}$ After the disintegration of the Soviet Union and discrediting the socialist project of modernity, Russia and other countries of the former Soviet bloc had no other choice but to 'join' the neoliberal capitalist modernity. ${ }^{51}$ This has opened the doors to discourses and practices of race, migration, and nationalism that might have been previously absent from the region or have appeared here in new forms. Sociological research attentive to these historical developments, striving for epistemic justice and willing to consider the role of the synchronous global contexts in structuring the meanings and practices of race can thus significantly contribute to the development of the decolonial project.

\footnotetext{
${ }^{49}$ Sergey Abashin, "Sovetskoe = kolonial'noe? (Za i protiv)," in Poniatiia o sovetskom v Tsentral'noi Azii: Al'manakh Shtaba № 2, eds. Georgy Mamedov, Oksana Shatalova (Bishkek, 2016), 47 [my translation from Russian].

${ }^{50}$ Abashin, "Sovetskoe = kolonial'noe?"

${ }^{51}$ Zakharov, Race and Racism in Russia; Madina Tlostanova, "Postsocialist $\neq$ postcolonial? On post-Soviet imaginary and global coloniality," Journal of Postcolonial Writing 48, no. 2 (May 2012): 130-142.
} 